\title{
Hak Asasi Manusia Kaitannya dengan Struktur Sosial Masyarakat
}

\author{
Habib Adji \\ Universitas Islam Bandung
}

Human rights are universal, granted by God to all humans since their birth, and have been recognized by nations as written in the United Nations Charter and in other multilateral treaties. However, every state has its own characteristics and values in relation to social structures, religions, and geographical condition. Therefore, it is difficult to make the point of view of states about human rights similar, in the sense that human rights problem in a state is impossible to resolve in the same way as that in others. If the problems of human rights are resolved without considering social structures, the society will be detached from their own social structures, and will be difficult to develop values living in the society.

Keywords: human rights, treaties, states, social structures

T uhan yang mahakuasa telah menciptakan berbagai suku bangsa yang bertebaran di muka bumi ini. Diciptakan adanya berbagai suku bangsa tersebut, agar satu suku bangsa dapat saling mengenal (ta'aruf) dengan suku bangsa yang lainnya. Hal tersebut telah tercantum dalam Al Qur'an surat 49:13 yang berbunyi:

"Hai manusia, sesungguhnya Kami menciptakan kamu dari seorang lakilaki, seorang perempuan dan menjadikan kamu berbaangsa-bangsa dan bersuku-suku supaya kamu saling kenalmengenal. Sesungguhnya orang yang paling mulia di antara kamu di sisi Allah ialah orang yang paling bertaqwa di antara kamu. Sesungguhnya Allah Maha MengetahuilagiMaha Mengenal." Kemudian suku bangsa yang berdiam atau menetap di suatu tempat tertentu memberikan identitas kepada dirinya sendiri, agar dapat dikenal oleh yang lainnya dan mereka membuat atau menciptakan aturan-aturan yang disesuaikan dengan situasi dan kondisi di mana mereka menetap, aturan-aturan (norma, nilai) tadi pada akhimya merupakan suatu sikap hidup atau budaya atau struktur sosial masyarakat yang telah terbina sesuai dengan perjalanan hidup suku bangsa yang bersangkutan. Oleh karena beragamnya suku bangsa (etnis) yang bertempat tinggal pada tempattempat tertentu, menyebabkan pandangan hidup ataupun struktur sosial masyarakat (suku bangsa) yang satu dengan yang lainnya tidaklah sama. Sehingga tiap suku bangsa mempunyai cara pandang yang tertentu terhadap masalah yang menjadi permasalahan semua bangsa, seperti pengertian atau pemahaman terhadap Hak Asasi Manusia.

Hak asasi merupakan hak yang paling dasar yang diberikan oleh Tuhan kepada manusia, misalnya hak untuk hidup, hak untuk berbicara dan mengeluarkan pendapat, dan pada prakteknya apabila ada suatu bangsa yang mencoba untuk mengebiri hak-hak tersebut, maka dapat 
dikatakan negara yang bersangkutan telah melakukan pelanggaran hak asasi manusia. Bahkan pelaksanaan hak asasi manusia di suatu negara sering dijadikan tolok ukur apakah negara yang bersangkutan dikategorikan negara demokrasi atau bukan atau juga oleh negara-negara yang sudah maju secara ekonomis yang akan memberikan bantuan kepada negara-negara di dunia ketiga dalam memberikan bantuan keuangan terkadang dikaitkan dengan pelaksanaan hak asasi manusia pada negara yang akan diberi bantuan tersebut, sudah tentu tolok ukur pelaksanaan hak asasi manusia tersebut bukan hanya didasarkan kepada nilaj-nilai kemanusiaan yang bersifat universal, tapi juga didasarkan kepada nilai-nilai yang dianut oleh negara yang akan memberikan bantuan.

Dengan mengkaji bahwa tiap bangsa yang ada di atas bumi ini sesuai dengan letak geografis yang berbeda sudah tentu akan mempunyai pandangan yang berbeda terhadap masalah hak asasi manusia, tapi bukan berarti secara tegas karena masih ada masalah hak asasi manusia yang diberikan persepsi yang sama oleh tiap bangsa (negara), hal ini sebagaimana yang dicanangkan oleh Perserikatan BangsaBangsa (PBB), bahwa hak asasi manusia adalah milik semua bangsa dan semua kebudayaan di dunia kita ini. Perjanjian antar bangsa (multilateral treaty) yang pertama, yang secara umum menyebut pentingnya hak asasi manusia adalah Charter PBB yang ditandatangani pada tanggal 26 Juni 1945 di San Fransisco. Dalam Charter ini terdapat kalimat tentang tujuan PBB yaitu dikatakan antara lain untuk meningkatkan "respect for human rights and fundamental freedoms for all, without distinction as to race, sex, language or religion".

Bahwa kenyataannya apa yang tersebut pada Charter PBB tersebut pada Char- ter PBB tersebut tidak bisa dilaksanakan sepenuhnya oleh negara-negara yang menjadi anggota PBB meskipun dalam keadaan yang darurat PBB memberikan batasan untuk melaksanakan hak asasi manusia seperti yang tercantum dalam pasal 2 ayat (3) ESCR Covenant yang menyatakan: "Developing countries ...., may determine to what extent they would guarantee the economic rights recognized in the present Covenant to non nationals".

ESCR (The International Covenant on Economic, Sosial and Cultural Rights) merupakan perjanjian internasional tentang -aturan-aturan hak asasi manusia, dan negara yang telah menandatangani perjanjian ini akan tunduk terhadap aturanaturan hak asasi manusia yang tersebut pada ESCR, di samping itu masih banyak perjanjian-perjanjian internasional lainnya tentang hak asasi manusia.

Pembatasan hak asasi manusia dalam keadaan yang darurat diperkenankan untuk sementara yaitu dalam hal perang atau keadaan darurat umum (public emergency) yang mengancam keselamatan negara. Tapi hal ini tidak bisa langsung berlaku secara otomatis, karena harus dapat diuji secara objektif. Dan tindakan yang diberlakukan yang mengurangi hak asasi manusia, harus dibatasi sejauh hal itu benar-benar diperlukan karena gawatnya keadaan (to the extent stricly required by exigencies of the situation). Namun demikian ada beberapa hak asasi manusia yang tidak dapat dikurangi atau dibatasi, meskipun dalam keadaan darurat misalnya: "the rights to life, the freedom from torture and other ill-treatment, the freedom from slavery and servitud, and the imposition of retroactive penal laws".

Seperti telah diuraikan di atas, bahwa tiap bangsa (negara) mempunyai pemahaman yang tersendiri tentang. hak asasi manusia, dan ini secara imperatif, sebenar- 
nya harus diterima oleh masyarakat internasional, dan jika hal ini dapat dimengerti, maka tidak perlu adanya intervensi negara lain terhadap pelaksanaan hak asasi manusia di negara lainnya.

Oleh karena itu terhadap hak asasi manusia, Indonesia mempunyai konsep hak asasi manusia sebagaimana yang tercantum pada Undang-Undang Dasar 1945 yaitu:

- Pasal 1 ayat 2 : bahwa rakyat pemegang kedaulatan yang dilakukan sepenuhnya oleh Majelis Permusyawaratan Rakyat.

- Pasal 27 ayat 1: Segala warga negara bersamaan kedudukannya di dalam hukum dna pemerintahan dan wajib menjunjung tinggi hukum dan pemerintah itu dengan tidak ada kecualinya.

- Pasal 27 ayat 2 : Tiap-tiap warga negara berhak atas pekerjaan dan penghidupan yang layak bagi kemanusiaan.

- Pasal 28:Kemerdekaan berserikat dan berkumpul, mengeluarkan pikiran dan tulisan dan sebagainya ditetapkan dengan undang-undang.

- Pasal 29 ayat 1: Negara menjamin kemerdekaan tiap-tiap penduduk utuk memeluk agamanya masing-masing dan untuk beribadat menurut agamanya dan kepercayaan itu.

- Pasal 30 ayat 1:Tiap-tiap warga negara berhak dan wajib ikut serta dalam usaha pembelaan negara.

- Pasal 31 ayat 1 : Tiap-tiap warga negara berhak mendapat pengajaran.

- Pasal 32 : Pemerintahan memajukan kebudayaan nasional Indonesia.

- Pasal 33 : hak untuk berekonomi.

- Pasal34 : Fakir miskin dan anak-anak terlantar dipelihara oleh negara.

Bahwa meskipun Indonesia telah mengatur dan menjalankan praktek hak asasi manusia sebagaimana yang tersebut dalam Undang-Undang Dasar 1945 dan peraturan perundangan laninnya., ternyata masih tetap dituding oleh negara-negara Barat (Amerika Serikat dan sekutunya), bahwa Indonesia telah banyak melakukan pelanggaran hak asasi manusia, dan untuk menangkal tudingan tersebut, kemudian pemerintah Indonesia membentuk "Komisi Nasional untuk mengurus masalah-masalah hak asasi manusia" yang pertama kalinya dipimpin oleh Ali Said, S.H. (alm) dan sekarang dipimpin oleh Munawir Sjadzali. Dengan adanya komisi ini menunjukkan bahwa Indonesia sangat berkepentingan (concern) dengan pelaksanaan hak asasi manusia.

Hak asasi manusia di suatu negara pada tahun 1993 ini telah menjadi sorotan dan perhatian negara-negara di dunia, dan untukmengatasinya pada tahun yang sama PBB telah memprakarsai suatu pertemuan di Wina-Austria untuk membicarakan masalah hak asasi manusia. Pertemuan ini semuanya diawali dengan adanya keinginan beberapa negara barat yang akan memberikan bantuan kepada negara-negara di dunia ketiga, selalu dikaitkan dengan pelaksanaan hak asasi manusia di negara yang akan menerima bantuan, bahkan PBB berkeinginan agar dapat bertindak secara langsung apabila ada suatu negara telah melanggar hak asasi manusia dengan terlebih dahulu membuat tolok ukurnya sendiri dengan tidak terlepas dari segala kepentingan Barat.

Sekarang timbul permasalahan, apakah pelaksanaan hak asasi manusia pada seluruh negara harus seragam? Sudah tentu dalam hal ini hak asasi manusia yang sudah dibawa sejak manusia lahir ke dunia harus dipertahankan dan siapapun tidak boleh melanggamya. 
Untuk memperjelas dan membahas permasaiahan tersebut di atas, sangat menarik apabila dikaitkan dengan dilakukannya "cekal" atau "cegah-tangkal" (yang pemah dilakukan) oleh pemerintah terhadap para anggota petisi 50 , dimana selama ini mereka tidak boleh melakukan segala kegiatan, bahkan dapat dikatakan telah mengalami "Kematian Perdata".

Tindakan yang dilakukan pemerintah tersebut dapat dikatakan telah melanggar hak asasi manusia atau melanggar pasal $28 \mathrm{UUD}$ 1945. Pemerintah melakukan tindakan tersebut untukmenjaga keamanan nasiona! dan kewibawaan pemerintah, berhubung kegiatan-kegiatan yang dila-kukan oleh Petisi 50 dianggap merongrong kewibawaan pemerintah pada tingkat nasional (dalam negeri) maupun luar negeri. Dan pemerintah memandang bahwa tindakan yang diambil tersebut tidak melanggar hak asasi manusia, karena tolok ukur yang dipergunakan untuk menyebut tindakan pemerintah melanggar hak asasi manusia atau tidak melanggar, tidak berdasarkan tolok ukur yang berlaku di negara-negara Barat yang liberal, tapi berdasarkan nilai-nilai yang hidup masyarakat Indonesia atau tidak terlepas dari struktur sosial masyarakat Indonesia, yaitu apabila ada yang tidak setuju dengan tindakantindakan pemerintah, pihak-pihakyang tidak setuju tidak perlu menyatakan ketidaksetujuannya dengan cara yang berlaku di negara-negara barat, tapi harus diselesaikan secara musyawarah untuk mufakat sehingga diperoleh jalan keluar yang memuaskan semua pihak. Cara penyelesaian masalah dengan musyawarah untuk mufakat merupakan nilai-nilai hidup bangsa Indonesia yang telah tertanam sepanjang perjalanan hidup bangsa Indonesia.

Térhadap tindakan yang diambil pemerintah tersebut telah mendapatkan reaksi dari berbagai pihak, baik dari dalam negeri maupun luar negeri. Dan tanggapan yang ada pada dasamya dapat dibagi menjadi dua bagian, yaitu:

1. Ada yang menyatakan setuju, dengan alasan bahwa, Indonesia sebagai negara yang sedang membangun memerlukan kondisi negara yang stabil, sehingga suara ketidaksetujuannya terhadap tindakan pemerintah dalam membangun negara-masyarakat ini, untuk sementara waktu perlu dicekal (cegah tangkal). Pemerintah memandang tindakannya tersebut telah sesuai dengan aspirasi yang ada.

2. Ada yang menyatakan tidak setuju, dengan alasan bahwa, apapun bentuk tindakan pemerintah yang mencekal hak-hak asasi manusia merupakan tindakan melanggar hak asasi manusia, dan hak asasi manusia itu bersifat universal juga tidak ada hak asasi manusia yang bersifat lokal (sesuai dengan negara yang bersangkutan). Bahwa jika dikaji kedua pendapat di atas, dapat kita sebutkan bahwa memang hak asasi manusia itu bersifat universal, hak yang diberikan Tuhan kepada manusia yang dibawa manusia sejak lahir yang dipunyai oleh semua makhluk yang namanya "manusia", dan hal itu sudah disepakati oleh negara-negara di dunia sebagaimana yang tercantum pada Charter PBB atau berdasarkan perjanjian-perjanjian internasional yang multitreaty, tapi tidak boleh dilupakan bahwa tiap negara yang ada di dunia ini mempunyai perbedaan-perbedaan tentang nilai-nilai (disparity of value) yang hidup di dalam masyarakatnya atau dengan kata lain bahwa struktur sosial masyarakat pada tiap negara berbeda-beda tergantung kepada beberapa aspek, misalnya keadaan geografi, agama.

Maka dari itu cara pandang tiap negara terhadap hak asasi manusia sulit untuk 
dibuat sama, artinya persoalan hak asasi manusia yang terjadi di suatu negara tidak mungkin diselesaikan dengan cara-cara yang berlaku di negara lain, tapi harus diselesaikan berdasarkan nilai-nilai yang - berlaku pada masyarakat negara yang bersangkutan. Apabila persoalan hak asasi manusia suatu negara diselesaikan dengan cara-cara atau tidak melihat struktur sosial masyarakat yang bersangkutan, maka masyarakat tersebut akan tercerabut dari strukturnya sosialnya sendiri dan akan mengalami kesulitan dalam mengembangkan nilai-nilai lain yang hidup di dalam masyarakat. Maka dari itu, hak asasi manusia tidak akan pernah terlepas dari nilai-nilai hidup atau struktur sosial masyarakat suatu negara.

\section{Daftar Pustaka}

Al Qur'an dan Terjemahannya. 1983. Departemen Agama Republik Indonesia, Proyek Pengadaan Kitab Suci Al Qur'an.

B. Simanjuntak. 1981. Tiga UU Dasar RI dan Sekitar Permasalahannya. Bandung: Tarsito.
Henkin, Louis. 1991. Pemyataan Hak Asasi Amerika dan Makna Internasionalnya, Majalah Hukum dan Pembangunan; Fakultas Hukum Universitas Indonesia, No. 6, Tahun $X X$.

Rahardjo, Satjipto. 1986. Hukum dan Masyarakat. Bandung:Angkasa.

Reksodiputro, Mardjono. 1991. Pemantauan Pelaksanaan Hukum Tentang Hakhak Asasi Manusia, Majalah Hukum dan Pembangunan, Fakultas Hukum Universitas indonesia, No. 6, Tahun XX.

Sunny, Ismail. 1992. HakAsasi Manusia di Indonesia, Majalah Hukum dan Pembangunan, Fakultas Hukum Universitas Indonesia, No. 3, Tahun XXII.

Universal Declaration of Human Rights \& The International Ovenant on Economic, Social, and Cultural Rigths, United Nations Publication, Sales No. E. 88.XIC.1. 